\title{
Antiplasmodial activities and abortifacient properties of three commonly used African indigenous anti-malarial plants in Plasmodium berghei infected pregnant mice: implication for maternal and fetal health
}

Ayodele S. Babalola ${ }^{* *}$ (D), Olufunmilayo A. Idowu', Kehinde O. Ademolu², J. Olukunle ${ }^{3}$ and Samson A. Rahman ${ }^{3}$

\begin{abstract}
Background: The use of herbs for malaria treatment is common among pregnant women in Nigeria. This study through a survey documented three most commonly used herbs in the management of pregnancy-associated malaria in Abeokuta, Nigeria. This study also evaluated the efficacy and abortifacient properties of the selected herbs against established Plasmodium berghei NK65 infection in 110 experimental pregnant mice randomly distributed into 22 groups and treated with extracts of Morinda lucida (L.) Benth. (Rubiaceae), Enantia chlorantha (oliv.) (Annonaceae), and Cymbopogon citatrus (Stapf) (Poaceae) at a graded dose of 100, 200, and $300 \mathrm{mg} / \mathrm{kg}$ and Sulphadoxine-pyrimethamine (Fansidar) at $10 \mathrm{mg} / \mathrm{kg}$.

Results: From the survey, Cymbopogon citratus (Leaf), Morinda lucida (Leaf), and Enanthia chlorantha (Bark) were the most frequently mentioned to be useful in management of malaria during pregnancy. Both M. lucida and E. chlorantha produced up to $70 \%$ P. gerghei chemosuppression in a dose dependent manner. Chemosupression was less than $50 \%$ in mice treated with C. citratus extracts. E. chlorantha induced abortion, while extracts of $C$. citratus and M. lucida caused miscarriage in pregnant mice. Progesterone titters were reduced in mice treated with plant extracts compared with those administered with Fansidar and untreated groups $(p<0.05)$.

Conclusion: This study showed that M. lucida and E. chlorantha had anti-malarial properties, which are promising in reducing problems with pregnancy associated malaria in the face of growing resistance to currently available drugs. However, they are capable of inducing abortion by impairing the production of progesterone. In order to reduce the risk of danger posed by use of herbs in pregnancy on mothers and the developing fetus, there is need for proper awareness on the possible abortifacient and teratogenic properties of herbs used in management of malaria during pregnancy.
\end{abstract}

Keywords: Pregnancy, Herbal, P. berghei, Oviduct, Endometrial, Hormones, Malaria

\footnotetext{
* Correspondence: ayodelebabalola2011@gmail.com

1 Malaria Research Unit, Department of Pure and Applied Zoology, Federal

University of Agriculture, Abeokuta, Nigeria

Full list of author information is available at the end of the article
}

\section{Springer Open}

(c) The Author(s). 2020 Open Access This article is licensed under a Creative Commons Attribution 4.0 International License, which permits use, sharing, adaptation, distribution and reproduction in any medium or format, as long as you give appropriate credit to the original author(s) and the source, provide a link to the Creative Commons licence, and indicate if changes were made. The images or other third party material in this article are included in the article's Creative Commons licence, unless indicated otherwise in a credit line to the material. If material is not included in the article's Creative Commons licence and your intended use is not permitted by statutory regulation or exceeds the permitted use, you will need to obtain permission directly from the copyright holder. To view a copy of this licence, visit http://creativecommons.org/licenses/by/4.0/. 


\section{Background}

Malaria affects mostly children under the age of 5 years and pregnant women in sub-Saharan Africa (Ukibe et al. 2014). Despite the fact that the effect of malaria in pregnancy is highly devastating, the choice of drug for prevention of malaria during pregnancy remained IPT-Sp. This might be only useful to those who attend hospitals for antenatal care during pregnancy (Babalola et al. 2017).

However, the use of traditional birth homes (TBHs) is a popular phenomenon among pregnant women in Nigeria and other African countries (Idowu et al. 2010). In a random survey carried out by other researchers in Nigeria, the level of patronages ranges from 35\% (Oshonwo et al. 2014) to as high as 75\% (Unyime et al. 2016) depending on the region. Few studies that assessed the management of malaria during pregnancy among pregnant women attending TBHs revealed that the traditional birth attendants (TBAs) often depends on herbs for management of malaria during pregnancy (Adeniran et al. 2016; Bello et al. 2011).

In recent times, natural products of plant sources have been the center of focus as the main source of new, safer, and more effective bioactive compounds with medicinal properties (Dike et al. 2012). Medicinal plants have been used in the treatment and prevention of malaria in various parts of the world. There is a need for screening plants used by pregnant women in order to ensure that pregnant women receive effective treatment. At the same time, such screening will also help to identify potentially unsafe use (toxicity), and preserve valuable information about medicinal plants for women's reproductive health for the future (Nergard et al. 2015).

The very few studies that have been published on women's use of medicinal plants during pregnancy from other African countries, such as from Ivory Coast (Malan and Neuba 2011), Nigeria (Fakaye et al. 2009; Yusuff and Omarusehe 2011), Zambia (Banda et al. 2007), Uganda (Kamatenesi-Mugisha and Oryem-Origa 2007), South Africa (Varga et al. 1997), Tanzania (Mbura et al. 1985), and Bénin and Gabon (Towns 2014), indicate a widespread use. However, the information about women's perceptions and knowledge about these medicinal plants are limited. Studies on the effects of herbs on pregnancy and neonates are very few and scarce (Fakeye et al. 2009). Although some herbalists and herb sellers claimed that herbs are safe for use by pregnant women for the treatment of malaria (Avwioro 2010). However, some studies suggested that some herbs could be teratogenic both in human and animal models (Pakrashi and Bhattacharya 1977; Seely et al. 2008). This paucity of scientific data continues to limit the understanding of events at the maternal-fetal interface with respect to treatment of malaria, especially the use of herbs.
The three plants used in this study, Morinda lucida, Enanthia chlorantha, and Cymbopogon citatrus, have been widely reported to possess some level of antimalarial properties (Idowu et al. 2014; Ebiloma et al. 2011; Kimbi and Fagbenro-Beyioku 1996; Ogbonna et al. 2008). Morinda lucida also called "Ezeogu, Oruwo, idonzakara" in Igbo, Yoruba, and Hausa respectively, has enjoyed a considerable level of recognition for the treatment of symptomatic malaria by many people in different parts of Nigeria (Afolabi and Abejide 2020). Cymbopogon citatrus also known as "Ncheawula, Koriko-oba, agusi" in Igbo, Yoruba, and Hausa respectively has also been reported to be widely used in different parts of Nigeria against malaria (Kimbi and Fagbenro-Beyioku 1996). Enantia chlorantha also known as Awopa or Dokitaigbo (Forest Doctor) in Yoruba is widely used in the Sothwestern part of Nigeria as an antimalarial agent (Ogbonna et al. 2008).

Malaria in pregnancy has recently attracted many research efforts. However, there are ethical and logistic issues that restrict studies of human malaria infection during pregnancy. As a result, specific pathologic bases of different pregnancy-associated malaria (PAM) outcomes remain poorly understood (Rogerson et al. 2007).

Hence, mice are often used for studying these complex systems and serve as developmental and functional models to understand human pregnancy, as both species have a hemochorial placenta exhibiting similar transport mechanisms (Rossant and Cross, 2001; Adamson et al. 2002). Hence, this study documented three most commonly used herbs in the management of pregnancyassociated malaria in Abeokuta, Nigeria, with a view to evaluate the efficacy and safety of the herbs using pregnant mice infected with Plasmodium berghei.

\section{Methods}

Survey of botanicals used in treatment of pregnancyassociated malaria in Abeokuta

Semistructured questionnaire was administered to TBAs in order to obtain information on the use of herbs in the treatment of malaria during pregnancy; the plant part(s) used, method of preparation, and mode of administration. Furthermore, information on attitude and use of herbal medicines among pregnant women were also sought for, using a separate (semistructured) questionnaire. The questionnaire was administered using interview method. Only participants that gave their consent after being briefed about the purpose of the study were recruited in the study. Their responses and identities were also kept anonymous.

\section{Plant collection, identification, and extraction}

Fresh leaves of $M$. lucida, C. citratus, and bark of $E$. chlorantha were collected from locations around Odeda Local Government, Abeokuta. Permission to collect the 
plants was granted by the state Ministry of Forestry and later by the owners of land where the plants were located. Visual identification and authentication were carefully done by a plant taxonomist Dr. Ekundayo of the Forestry Research Institute of Nigeria (FRIN). The plant specimens were deposited in the herbarium with voucher numbers.

\section{Preparation of crude extract}

The plant parts were washed, dried at room temperature $\left(28 \pm 2{ }^{\circ} \mathrm{C}\right)$, and then pulverized using plant grinder. These were soaked separately in distilled water for $24 \mathrm{~h}$ and later filtered. The filtrates were afterward evaporated to dryness (semi-solid state) over water bath at $35^{\circ} \mathrm{C}$ for further use (Idowu et al. 2014).

\section{Source of animals}

A total of 110 female BALB/c mice (each weighing between 23.0 and $23.2 \mathrm{~g}$ ) with mean weight of $23.2 \pm 0.2 \mathrm{~g}$ and same physiological age commercially obtained from Nigerian Institute of Medical Research (NIMR), Yaba, were used for this study. The mice were free of pathogens, and have not been used for any initial experiment.

\section{Animal housing and husbandry}

The mice were kept in plastic cages which contained dried wood shavings as beddings at room temperature $\left(28 \pm 2{ }^{\circ} \mathrm{C}\right)$ and were fed with standard ration (Vital Feeds Limited, Ibadan) and clean water in the animal house. The mice were kept at 12-h light and dark cycle.

\section{Experimental design}

A total of 110 mice (each weighing between 23.0 and $23.2 \mathrm{~g}$ ) were randomly divided into 22 groups of 5 pregnant mice each. Eleven out of the pregnant groups were infected at low inoculum at gestation day (GD) 6. Treatment started at GD 9 and lasted for 6 days; nine (9) groups were given plant extracts. A group was treated with Sulphadoxine-pyrimethamine (positive control) while a group was not treated (negative control). Remaining non-infected groups were subjected to the same treatment (Table 1). On
GD 18, three out of five mice in each group were euthanized by cervical dislocation. This is to prevent the possibility of the results (especially the hormonal assay) being affected by applying overdose of a euthanizing agent (e.g., sodium thiopentone or Ketamine). The remaining animals were allowed to litter for further studies.

\section{Experimental procedures}

\section{Treatment of infected and non-infected pregnant mice}

Leaves extracts of M. lucida and C. citratus and bark extract of E. chlorantha were administered to the pregnant mice orally with the aid of an oral cannula at 3 different dosages; $100 \mathrm{mg} / \mathrm{kg}, 200 \mathrm{mg} / \mathrm{kg}$, and $300 \mathrm{mg} / \mathrm{kg}$ body weight respectively (Abolaji et al. 2012). Sulphadoxine pyremethamine (SP) was administered at a dosage of 10 $\mathrm{mg} / \mathrm{kg}$ body weight. The dosages were selected following the method of (Pakrashi and Bhattacharya 1977). We therefore administered the extracts at a dose that is not toxic in non-pregnant mice. The lowest dose $(100 \mathrm{mg} / \mathrm{kg}$ body weight) was lower than $10 \%$ of the $\mathrm{LD}_{50}$ while the highest dose $(300 \mathrm{mg} / \mathrm{kg}$ body weight) was lower than $20 \%$ of the $\mathrm{LD}_{50}$

\section{Oestrus synchronization and mating}

A method for inducing oestrus and proestrus in female mice by exposing them to bedding soaked with male urine (Whitten effect) (Dalal et al. 2001) was used. Sexually matured females (at least 60 days old) were housed for 1 week. Sexually mature male mice (at least 60 days old) were separately housed for 1 week. The females were then exposed for 4 days to bedding soaked with male urine; one male were placed with a pair of naturally synchronized females for a period of $48 \mathrm{~h}$ in order to generate timed pregnant females.

\section{Parasites}

Malaria parasites $P$. berghei NK 65 obtained from a stock maintained at the Institute for Advance Medical Research and Training, University College Hospital (UCH) Ibadan were used. These were prepared as an inoculum.

Table 1 Experimental groups

\begin{tabular}{|c|c|c|c|c|c|c|}
\hline \multirow[t]{2}{*}{ Groups } & \multirow{2}{*}{$\begin{array}{l}\text { Pregnancy } \\
\text { status }\end{array}$} & \multirow{2}{*}{$\begin{array}{l}\text { Infection } \\
\text { status }\end{array}$} & \multirow{2}{*}{$\begin{array}{l}\text { Treatment } \\
\text { status }\end{array}$} & \multicolumn{2}{|c|}{ No of groups } & \multirow{2}{*}{$\begin{array}{l}\text { Total } \\
\text { Group }\end{array}$} \\
\hline & & & & Treatment & $\overline{\text { Dosage }}$ & \\
\hline 1 & Pregnant & Infected & Plants (3 plants) & 3 & 3 & 9 \\
\hline 2 & pregnant & infected & Treatment(SP) & 1 & 1 & 1 \\
\hline 3 & pregnant & infected & No treatment & 1 & 1 & 1 \\
\hline 4 & pregnant & not infected & No treatment & 1 & 1 & 1 \\
\hline 5 & pregnant & not infected & Plants (3 plants) & 3 & 3 & 9 \\
\hline 6 & pregnant & not infected & Treatment (SP) & 1 & 1 & 1 \\
\hline Total & & & & & & 22 \\
\hline
\end{tabular}

Three plants extracts were evaluated in this study at 3 different dosages (100, 200, and $300 \mathrm{mg} / \mathrm{kg}$ body weight). SP Sulphadoxine pyrimethamine 


\section{Inoculation of experimental mice}

Malaria parasite inoculums were prepared by collecting blood samples from donor mouse. The blood collected from the donor mouse was then diluted with normal saline such that $0.1 \mathrm{ml}$ contained $10^{3}$ of the parasite.

One hundred ten (110) mice were divided into twentytwo (22) groups of five mice each; all the mice were infected with the parasites by inoculating them intraperitoneally with $0.1 \mathrm{ml}$ of the prepared blood solution.

\section{Measurement of experimental outcomes \\ Estimation of percentage chemosuppression}

Each day, blood samples were taken from the caudal vein of each mouse on a clean glass slide; thin films were prepared and stained with $10 \%$ Giemsa solution. The parasitaemia was estimated by careful examination of the well-stained thin blood film. Parasitaemia was determined by dividing the number of parasitized red blood by the total number of red blood cells and then multiplied by 100 to express it as a percentage.

Percentage malaria parasitaemia (\%) and day 6 chemosuppression (\%) were determined using the formula below:

$$
\begin{aligned}
& \text { Percentage malaria parasitaemia }(\%) \\
& \text { Number of parasitized RBC } \\
& \text { Total number of RBC counted }
\end{aligned} 100
$$

Day 6malariachemosuppression

$$
=\frac{\text { MP of untreated }- \text { MP of treated }}{\text { MP of untreated }} \times 100
$$

where MP is the percentage malaria parasitaemia

\section{Determination of abortifacient properties using oviduct histology and progesterone level}

Oviduct of mice assumed to be pregnant without fetus and traces of implantations upon dissection were crosssectioned. The presence of prominent endometrial gland(s) in the section was taken as indication of disrupted pregnancy. Progesterone level was determined using the method of Riberio et al. (2012).

\section{Determination of fetal weight, number, and mortality rate}

At gestational day 18, 3 mice each were dissected; number of fetus were counted, number of live fetus were counted against the total, and multiplied by 100 to give percentage mortality. The fetus were also weighed using a digital weighing scale (Mettler Tolebo Veritas scale for laboratory with model number ES 422).

\section{Statistical analysis}

Raw data obtained from the laboratory were analyzed using one-way analysis of variance (ANOVA) to compare means across groups using Statistical Product and Service Solution (SPSS), version 21.0 (Chicago, IL). The results were presented as mean $\pm \mathrm{SE}$ in tables. Mean values with $p<0.05$ were considered significant.

\section{Results}

Response on common antimalarial plants and parts used by pregnant women in Abeokuta

About 17 different herbs were listed to be useful in treatment of malaria in pregnancy by both pregnant women and traditional practitioners (TPs) (TBAs refused to disclose the herbs used). The most commonly mentioned plants were Cymbopogon citratus (pregnant and older women $=31.98 \%$, traditional practitioners $=26.37 \%$ ), followed by Morinda lucida (pregnant and older women $=17.57 \%$, TPs $=27.47 \%$ ) and Enanthia chlorantha (pregnant and older women $=12.61 \%$, traditional practitioners $=8.29 \%$ ) $($ Table 2$)$. Other plants mentioned includes Morinda morindiodes (pregnant and older women $=6.31 \%$, TPs $=$ 4.40\%), Azadirachta indica (pregnant and older women $=6.31 \%$, TPs $=2.20 \%$ ), and Bambosa vulgaris among others (Table 2).

The major plants parts used in treatment of malaria is the leaves; other parts includes stem bark, fruits, seeds, root bark, stem, and root (Table 2). The various solvents for herbal preparations mentioned are water, aqueous extract from fermented maize, and carbonated drink (7up). Furthermore, water was the most preferred solvent by most respondents for the preparation of herbal medicines of choice. However, some of them squeeze the leaves with little or no water (Table 2).

Some of the herb sellers claimed that E. chlorantha can possibly induce abortion when used. Hence, they sometimes preferred not to administer it to pregnant women. Generally, knowledge of malaria symptoms was fair among the TPs and they boldly claimed that herbs can be used in treatment of all forms of malaria.

\section{Attitude of the pregnant women toward exclusive usage of antimalarial herbs during pregnancy}

Majority of the pregnant women claimed not to solely depend on TBH alone for antenatal care. Despite this, most of them did not receive intermittent preventive treatment (IPT). Most of these pregnant women preferred taking herbs believing that it is safer than conventional drugs. They were however unaware of the teratogenic and/or abortifacient potentials of herbs. 
Table 2 Response on common antimalarial plants and parts used in Abeokuta

\begin{tabular}{|c|c|c|c|c|c|c|}
\hline \multirow[t]{2}{*}{ Vernacular name } & \multirow[t]{2}{*}{ Botanical name } & \multicolumn{2}{|c|}{ Pregnant and Older women } & \multicolumn{2}{|c|}{ TBH and Herb sellers } & \multirow[t]{2}{*}{ Methods of preparation } \\
\hline & & Frequency (\%) & Plant parts & Frequency (\%) & Plant parts & \\
\hline Ewe tea & Cymbopogon citratus (S) & 31.98 & $L$ & 26.37 & L & Fermented maize/water \\
\hline Oruwo & Morinda lucida L. (benth) & 17.57 & L & 27.47 & L & Squeezing and boiling in water \\
\hline Awopa & Enanthia chlorantha (Oliv.) & 12.61 & S.B & 8.29 & S.B & Soak in 7up, water \\
\hline Ponju owiwi & Morinda morindiodes Bark. & 6.31 & R.B, Sm & 4.40 & R.B, Sm & Boiled in water \\
\hline Dongoyaro & Azadirachta indica A. Juss & 6.31 & $\mathrm{~L}, \mathrm{Sd}$ & 2.20 & $L, S d$ & Boiled in water \\
\hline Goba & Psidium guajava & 6.31 & $\mathrm{~F}$ & 0.00 & $\mathrm{~F}$ & NA \\
\hline ljagoin & Citrus aurantifolia & 4.95 & $\mathrm{~F}$ & 2.20 & $\mathrm{~F}$ & Boiled in water \\
\hline Eepo ahun & Alstonia boonei De Wild. & 4.95 & S.B & 2.20 & $S . B$ & Boiled in water \\
\hline Ewuro & Vernonia amygdalina Del. & 4.05 & L & 2.20 & L & Squeezing and boiling in water \\
\hline Aridantoro & Cassia fistulosa Lam. & 2.25 & L, S.B & 3.30 & $L, S . B$ & Boiled in water \\
\hline Mangoro & Magnifera indica L. & 1.35 & L & 2.20 & L & Fermented maize/water \\
\hline Ibepe & Carica papaya L. & 1.35 & $\mathrm{~F}$ & 2.20 & $L, F$ & boiled in water \\
\hline Orogbo & Garcina kola (Heckel) & 0.90 & S.B & 0.00 & S.B & NA \\
\hline Oparun & Bambosa vulgaris & 0.45 & L & 2.20 & L & Fermented maize/water \\
\hline Otili & Cajanus cajan Millsp. & 0.45 & L & 0.00 & L & NA \\
\hline Osan wewe & Citrus medica & 0.00 & $L, F$ & 6.59 & $L, F$ & Boiled in water \\
\hline Laali & Lawsonia inermis L. & 0.00 & L & 2.20 & L & Fermented maize/water \\
\hline
\end{tabular}

Column with ${ }^{a}$ represents herbs can induce abortion as claimed by herb sellers. $L$ leaves, $F$ fruits, $S . B$ stem bark, $S d$ seed, $S m$ stem, $R . B$ root bark

\section{Antiplasmodial properties of the three most frequently mentioned plants used by pregnant women in Abeokuta}

There was a dose-dependent increase in percentage chemosuppression of parasitaemia in infected pregnant mice treated with the three plant extracts (Table 3). M. lucida extract produced the highest chemosuppression $(>70 \%$ at 200 $\mathrm{mg} / \mathrm{g}$ and $300 \mathrm{mg} / \mathrm{g}$ body weight respectively) compared with other extracts at all dosages $(p<0.05)$. E. chlorantha extract was able to produce $>70 \%$ chemosuppression of parasitaemia at $300 \mathrm{mg} / \mathrm{g}$ body weight. The results further showed that $C$. citratus produced the least chemosuppression of parasitaemia $(<60 \%)$ at all the dosages (Table 3 ).

\section{Effect of plant extracts on pups weight, number and} mortality of infected and non-infected pregnant mice Generally, fetal weight and number were lower, while mortality and miscarriages were higher in the infected pregnant mice compared with the non-infected pregnant mice $(p<0.05)$ (Table 4$)$. Upon dissection, fetus from both infected and non-infected pregnant mice treated with extracts of Cymbopogon citratus recorded lower weight compared with the control groups (untreated and fansidar) (Table 4). However, no significant difference ( $p$ $>0.05$ ) exists between groups treated with Morinda lucida extracts and the untreated group. Infected pregnant mice treated with extracts of Cymbopogon citratus recorded lower fetal number compared to the control groups. Furthermore, groups treated with Morinda lucida extracts recorded higher fetal number compared to the untreated group (Table 4). Group treated with fansidar recorded the highest number of fetus. The difference observed was statistically significant $(p<0.05)$.

Fetal death and number of miscarriage (Plate 1) increased with increase in dosage across all the groups treated with plant extracts with the highest mortality and number of miscarriage recorded in infected groups treated with $300 \mathrm{mg} / \mathrm{kg}$ body weight of Cymbopogon citratus, and M. lucida $(p<0.05)$ respectively (Table 4$)$.

Table 3 Chemosupression in treated and control groups of pregnant infected mice at day 6

\begin{tabular}{|c|c|c|c|c|}
\hline \multirow[t]{2}{*}{ Groups } & \multirow{2}{*}{$\begin{array}{l}\text { No. of mice } \\
\text { analyzed }\end{array}$} & \multicolumn{3}{|c|}{ Concentrations (mg/kg body weight) } \\
\hline & & 100 & 200 & 300 \\
\hline E. chlorantha & $5 / 5$ & $58.82 \pm 3.45^{a}$ & $66.10 \pm 0.33^{b}$ & $74.32 \pm 0.57^{c}$ \\
\hline C. citratus & $5 / 5$ & $44.83 \pm 2.89^{a}$ & $46.15 \pm 0.76^{\mathrm{a}}$ & $55.56 \pm 0.76^{b}$ \\
\hline M. lucida & $5 / 5$ & $67.24 \pm 0.24^{\mathrm{a}}$ & $70.83 \pm 0.48^{a b}$ & $77.26 \pm 0.69^{c}$ \\
\hline Fansidar (Control) & $5 / 5$ & $100.00 \pm 00$ & - & - \\
\hline
\end{tabular}

Values were expressed as mean \pm standard error of mean (S.E.M). Values with different superscripts (Alphabets) in a row are significantly different ( $p<0.05)$ 
Table 4 Effect of plant extracts on fetal weight, number and mortality of infected and non-infected pregnant mice (before littering)

\begin{tabular}{|c|c|c|c|c|c|c|c|c|}
\hline \multirow{2}{*}{$\begin{array}{l}\text { Groups (mg/kg } \\
\text { body weight) }\end{array}$} & \multicolumn{2}{|c|}{ Fetal weight (g) } & \multicolumn{2}{|l|}{ Fetal number } & \multicolumn{2}{|c|}{ Fetal mortality (\%) } & \multicolumn{2}{|c|}{$\%$ Miscarriage } \\
\hline & Infected & Non-infected & Infected & Non-infected & Infected & Non-infected & Infected & Non-infected \\
\hline C. citratus 100 & $0.71 \pm 0.01^{\mathrm{a}}$ & $0.97 \pm 0.14^{b}$ & $4.67 \pm 0.67^{a}$ & $7.00 \pm 0.58^{b}$ & $7.07^{\mathrm{b}}$ & $0.00^{\mathrm{a}}$ & $20.00^{b}$ & $0.00^{\mathrm{a}}$ \\
\hline C. citratus 200 & $0.61 \pm 0.02^{\mathrm{a}}$ & $0.98 \pm 0.10^{b}$ & $5.33 \pm 0.33^{\mathrm{a}}$ & $6.33 \pm 0.33^{b}$ & $37.53^{b}$ & $0.00^{\mathrm{a}}$ & $40.00^{b}$ & $20.00^{\mathrm{a}}$ \\
\hline C. citratus 300 & $0.53 \pm 0.01^{\mathrm{a}}$ & $0.83 \pm 0.10^{b}$ & $8.00 \pm 0.58^{b}$ & $6.00 \pm 1.00^{\mathrm{a}}$ & $62.50^{\mathrm{b}}$ & $25.50^{\mathrm{a}}$ & $60.00^{b}$ & $40.00^{\mathrm{a}}$ \\
\hline M. Iucida 100 & $0.88 \pm 0.02^{\mathrm{a}}$ & $1.11 \pm 0.13^{\mathrm{b}}$ & $8.00 \pm 0.58^{b}$ & $7.67 \pm 0.67^{\mathrm{ab}}$ & $25.00^{b}$ & $0.00^{\mathrm{a}}$ & $40.00^{b}$ & $0.00^{\mathrm{a}}$ \\
\hline M. lucida 200 & $0.90 \pm 0.07^{\mathrm{a}}$ & $1.08 \pm 0.10^{\mathrm{b}}$ & $7.83 \pm 1.76^{b}$ & $9.00 \pm 0.58^{b}$ & $19.54^{b}$ & $11.11^{\mathrm{a}}$ & $20.00^{\mathrm{a}}$ & $40.00^{b}$ \\
\hline M. lucida 300 & $0.91 \pm 0.07^{\mathrm{a}}$ & $1.07 \pm 0.10^{b}$ & $6.67 \pm 0.33^{\mathrm{a}}$ & $8.00 \pm 0.58^{b}$ & $55.02^{b}$ & $24.13^{\mathrm{a}}$ & $60.00^{\mathrm{b}}$ & $40.00^{\mathrm{a}}$ \\
\hline Untreated & $0.70 \pm 0.06^{\mathrm{a}}$ & $1.21 \pm 0.13^{b}$ & $7.67 \pm 1.45^{\mathrm{a}}$ & $10.67 \pm 0.67^{b}$ & $0.00^{\mathrm{a}}$ & $0.00^{\mathrm{a}}$ & $0.00^{\mathrm{a}}$ & $0.00^{\mathrm{a}}$ \\
\hline Fansidar (SP) & $0.98 \pm 0.33^{a}$ & $1.10 \pm 0.06^{\mathrm{ab}}$ & $12.67 \pm 0.88^{b}$ & $10.33 \pm 0.33^{a}$ & $0.00^{\mathrm{a}}$ & $0.00^{\mathrm{a}}$ & $0.00^{\mathrm{a}}$ & $0.00^{\mathrm{a}}$ \\
\hline
\end{tabular}

Values were expressed as mean \pm standard error of mean (S.E.M). Values with different superscripts (alphabets) in a column are significantly different ( $p<0.05$ ) Mean values presented were from three dissected mice from a total of five in each group

Fetal mortality and miscarriage were not recorded in the untreated and fansidar groups (Table 4).

Furthermore, dislodgement of embryo were observed in uterus of mice treated with plant extracts compared to that of untreated mice (Plate 2). No fetus was

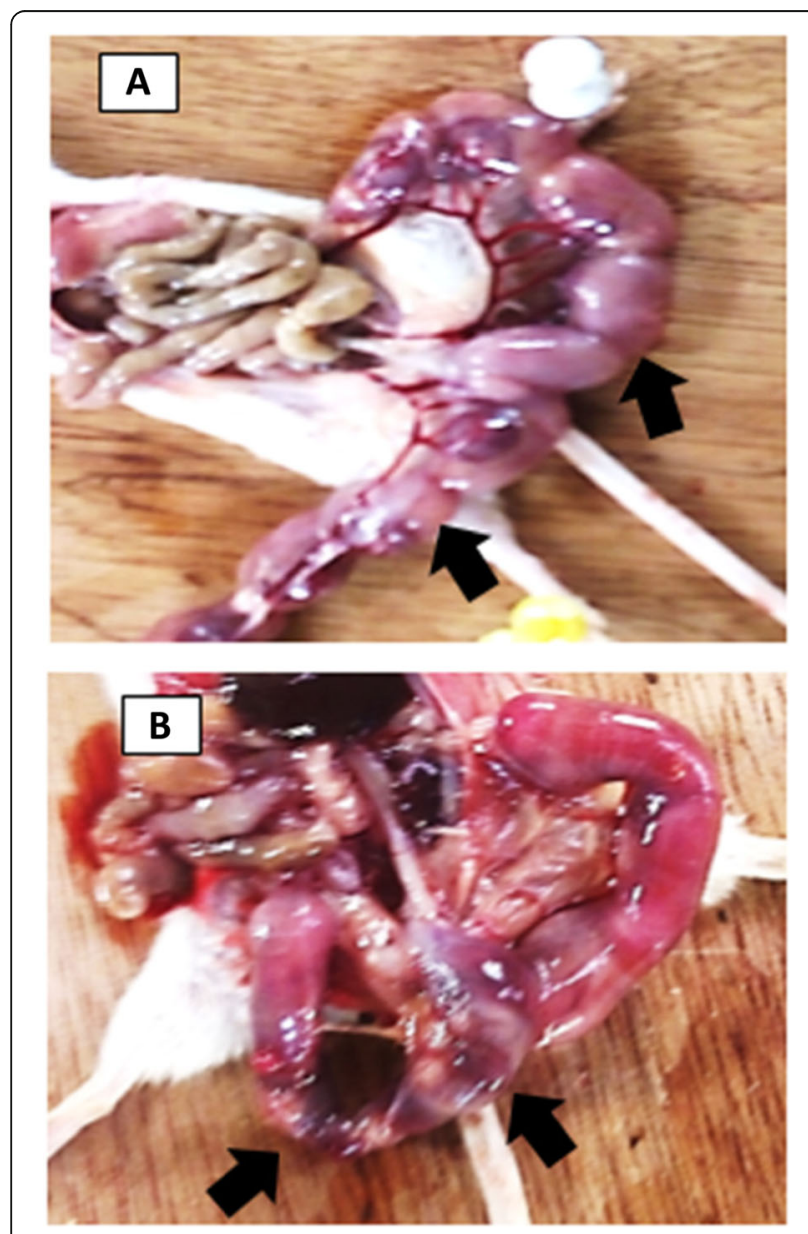

Plate 1 Uteri of mice showing; normal uterus (control) (a), miscarriage and rupture of the mouse's uterus (treated) (b) recovered in pregnant mice treated with extracts of $E$. chlorantha (suspected abortion)

\section{Determination of abortifacient property of E. chlorantha extract (oviduct histopathology)}

Well-developed endometrial glands were observed in the oviduct of mice examined for suspected abortion (Plate 3). Furthermore, the number of glands reduced with increase in dosage. The glands were more developed in the noninfected mice compared to the infected mice. On the other hand, the gland was not developed in oviduct of non-pregnant (control) mouse (Plate 3). The uterus of the mice also indicates signs of fetal reabsorption and implantation sites (Plate 4).

\section{Effect of different plant extracts on progesterone level of infected and uninfected pregnant mice}

Progesterone levels in mice treated with plants extracts were significantly lower $(p<0.05)$ compared with the control (untreated and fansidar) group. Pregnant mice treated with $E$. chlorantha recorded the least values ( $p<$ 0.05 ) for progesterone compared with other plants used in this study. A significant decrease $(p<0.05)$ in serum progesterone level were observed in all infected mice treated with the three plant extracts (Fig. 1). These decrease becomes more prominent with increase in concentration of plant extracts administered to the pregnant mice.

Similarly, significant decrease $(p<0.05)$ in serum progesterone level was observed in all non-infected mice treated with the three plant extracts (Fig. 1). However, progesterone level was significantly higher $(p<0.05)$ in the non-infected pregnant mice compared to the infected pregnant mice (Fig. 1).

\section{Discussion}

In this study, majority of the pregnant women claimed not to solely depend on TBH alone for antenatal care. Despite this, most of them did not receive intermittent 


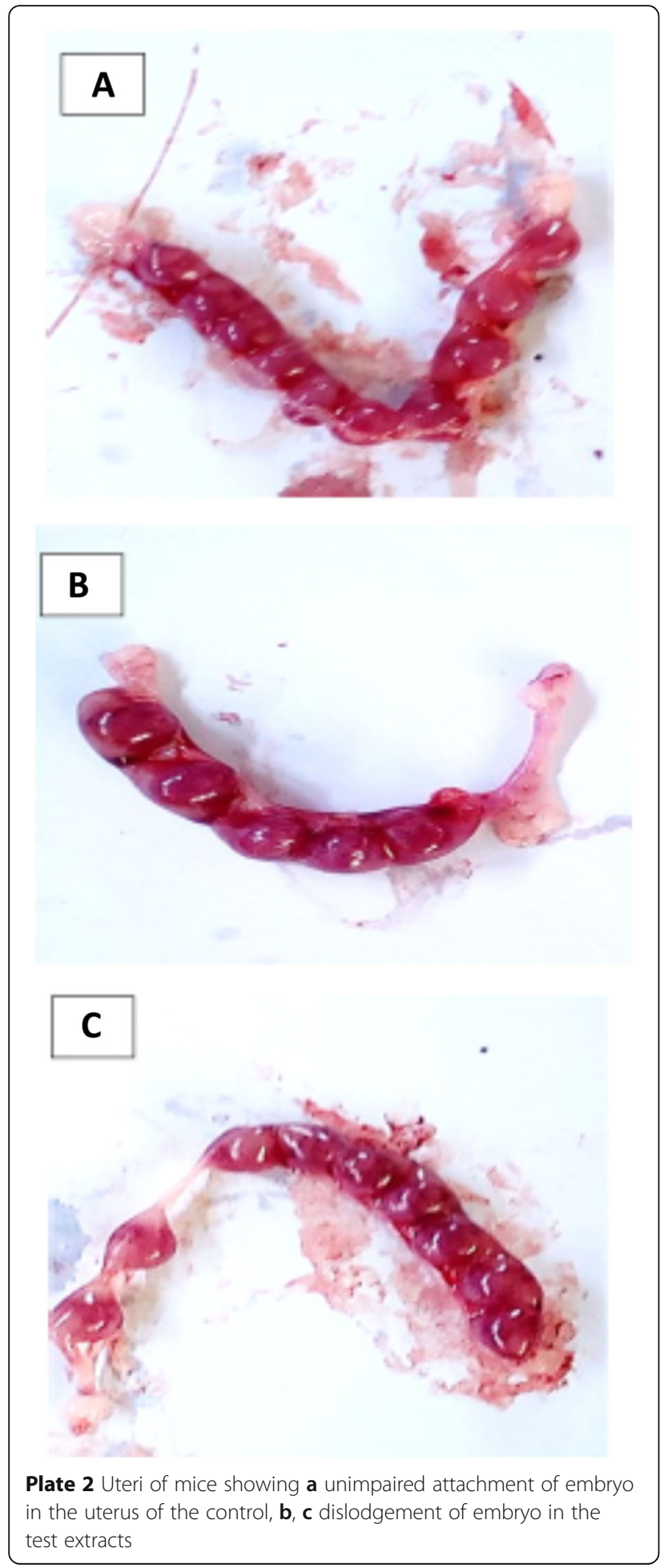

preventive treatment (IPT). A study in Abeokuta showed that most of the parturients that failed to use IPT during pregnancy claimed that they were given IPT, but only pretended to swallow it during their antenatal visits (Babalola et al. 2015). More so, majority of these pregnant women preferred taking herbs believing that it is

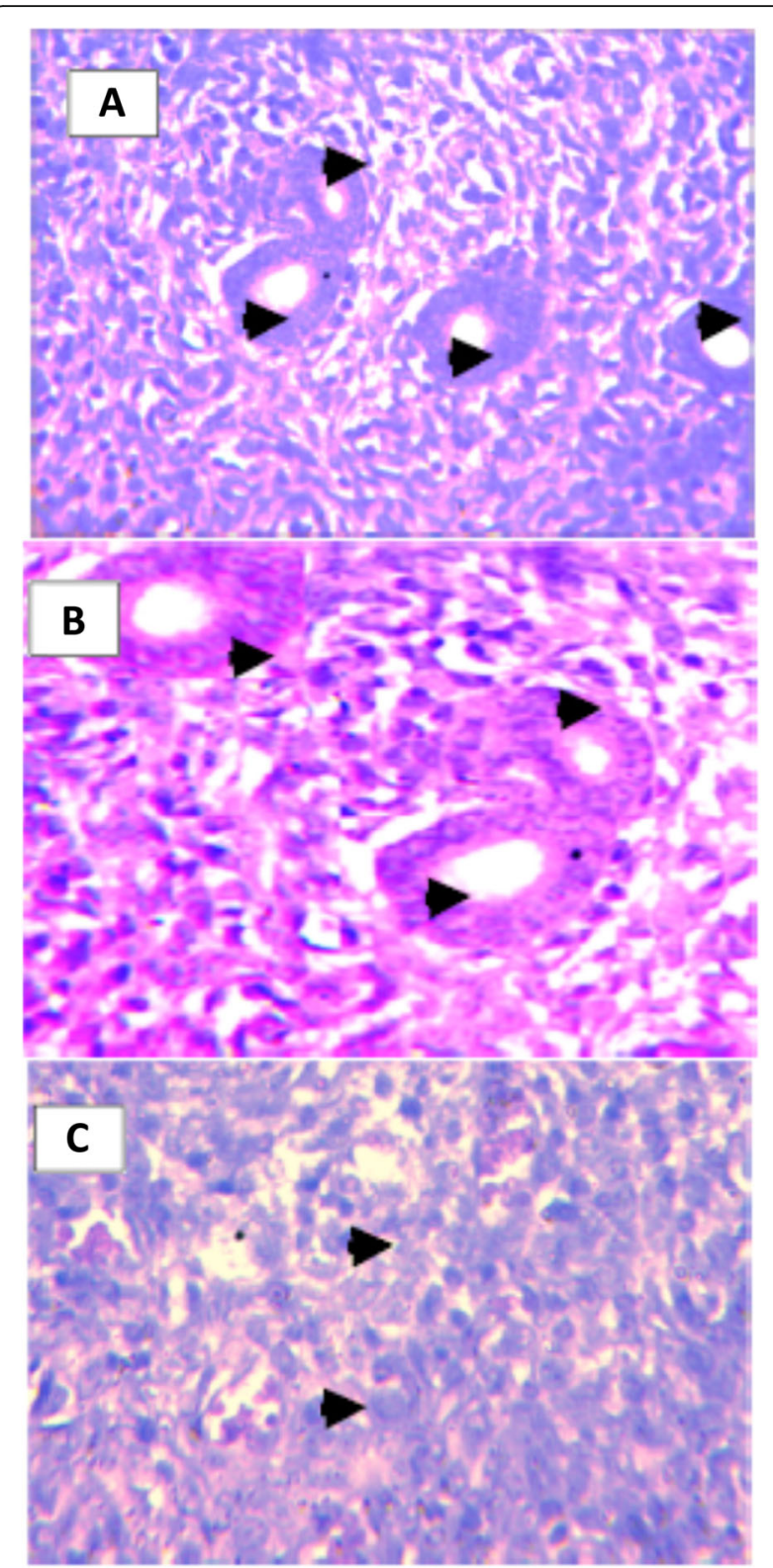

Plate 3 Section of the oviduct showing a treated non-infected pregnant, $\mathbf{b}$ treated infected, $\mathbf{c}$ non-pregnant control $(\mathbf{a}, \mathbf{b})$ welldeveloped endometrial gland, and $\mathbf{c}$ endometrial gland not developed. $\mathrm{H}$ and $\mathrm{E} \times 400$

safer than conventional drugs. They were however unaware of the teratogenic and/or abortifacient potentials of herbs. Other studies from Nigeria (Fakaye et al. 2009) and other African countries (Astin 1998; Maroyi 2013) reported similar findings.

TBAs refused to disclose the herbs used in treatment of malaria. Information on herbs used in malaria treatment were obtained mainly from herb sellers (in which some of them were reluctant) and pregnant women who sourced their herbs from other means apart from TBAs. Idowu et al. (2008) identified this situation as a major 

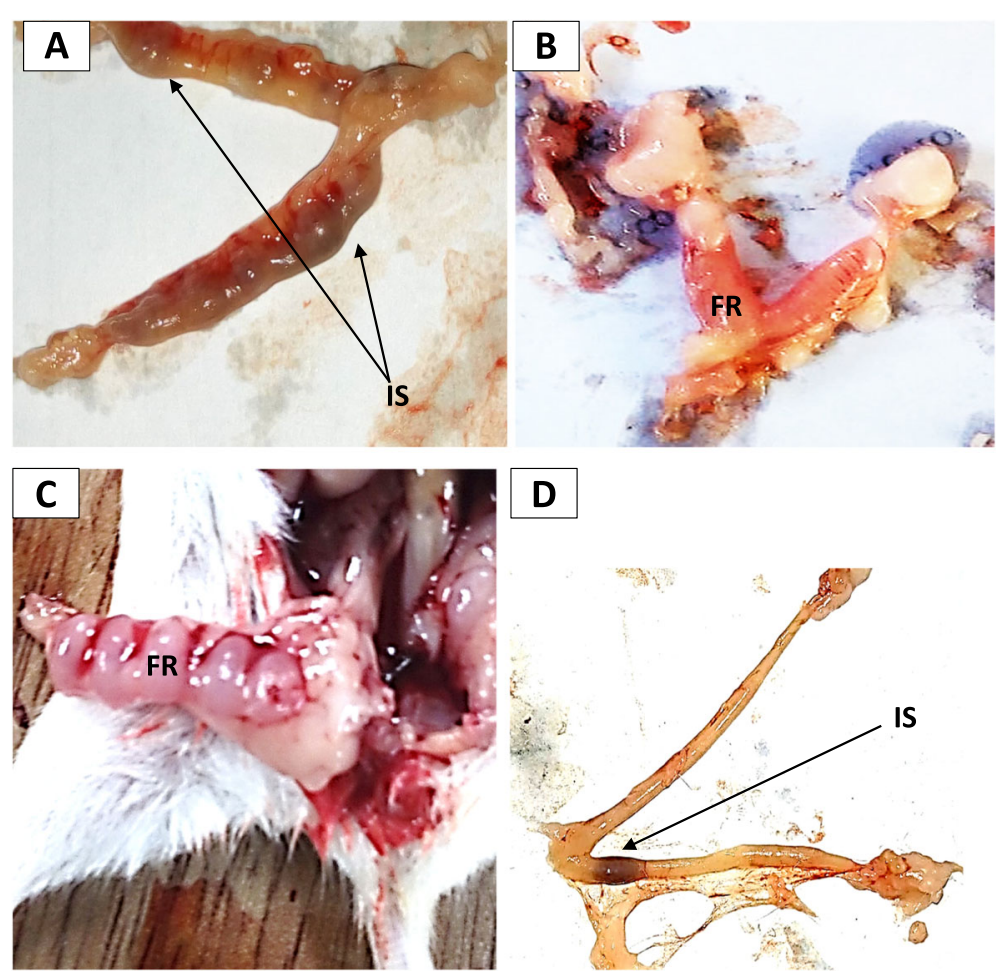

Plate 4 Uterus of mice with suspected abortion showing $\mathbf{a}, \mathbf{b}$ implantation sites [IS] and $\mathbf{b}, \mathbf{c}$ fetal resorption (FR)

setback in the documentation of essential herbs in the treatment of malaria as used by traditional healers in Nigeria.

All the traditional practitioners boldly claimed that herbs were effective in malaria treatment during pregnancy and are relatively safer (for both mothers and developing fetus) compared with conventional drugs. These findings corroborate that of Kazembe et al. (2012). However, it is relieving to know that a good proportion of the respondents are aware that not all antimalarial herbs could be used during pregnancy as they can induce abortion.

Knowledge of malaria symptoms was generally fair among the traditional practitioners. This observation supports the findings of Adeniran et al. (2016). However, all the traditional practitioners claimed to exclusively treat pregnancy-associated malaria (PAM) with herbs. These findings have serious implications for malaria control (Idowu et al. 2008).

About 17 different herbs were listed to be useful in treatment of malaria in pregnancy by both pregnant women and traditional practitioners. The herbs that made the top three were $C$. citratus, $M$. lucida, and $E$. chlorantha. These findings were similar to other findings on ethno-botanical survey of antimalarial plants used in Abeokuta (Idowu et al. 2010). These plants have also been reported to be used by pregnant women in other parts of Nigeria (Olajide and Adekemi 2020) and other African Counties (Malan and Nueba 2011).
A study from Abeokuta attributed the antiplasmodial properties of Morinda lucida to anthraquinones (Idowu et al. 2010). E. chlorantha and C. citatrus also possesses antimalarial properties attributed to alkaloids, terpenes and flavanolids (Ukpai and Amaechi 2012; Adebiyi and Abatan 2013).

Water was the preferred liquid by most respondents for the preparation of herbal medicines of choice. This finding is in line with another study from Nigeria (Fakeye et al. 2009). Water has been considered an inert liquid that will ensure adequate extraction of watersoluble constituents from plant materials (Fakaye et al. 2009).

This study further investigated the antiplasmodial effects of three (most frequently mentioned) plant extracts in a 6-day treatment of $P$. berghei-infected (pregnant and non-pregnant) mice.

Leaf extract of $M$. lucida in this study demonstrated a chemosuppression up to $77 \%$ in pregnant in a 6-day treatment. This is consistent with the findings of Ebiloma et al. (2011) and Idowu et al. (2014) who reported that the in vivo antiplasmodial activity of aqueous leaf extract of M. lucida carried out in P. berghei NK-65 parasitized mice showed a significant chemosuppression of up to $85.05 \%$ and $84.7 \%$ respectively. Studies from the phytochemical screening of the aqueous leaf extract of M. lucida revealed the presence of alkaloids and flavonoid as the predominant secondary metabolite (Ebiloma et al. 2011). Therefore, 

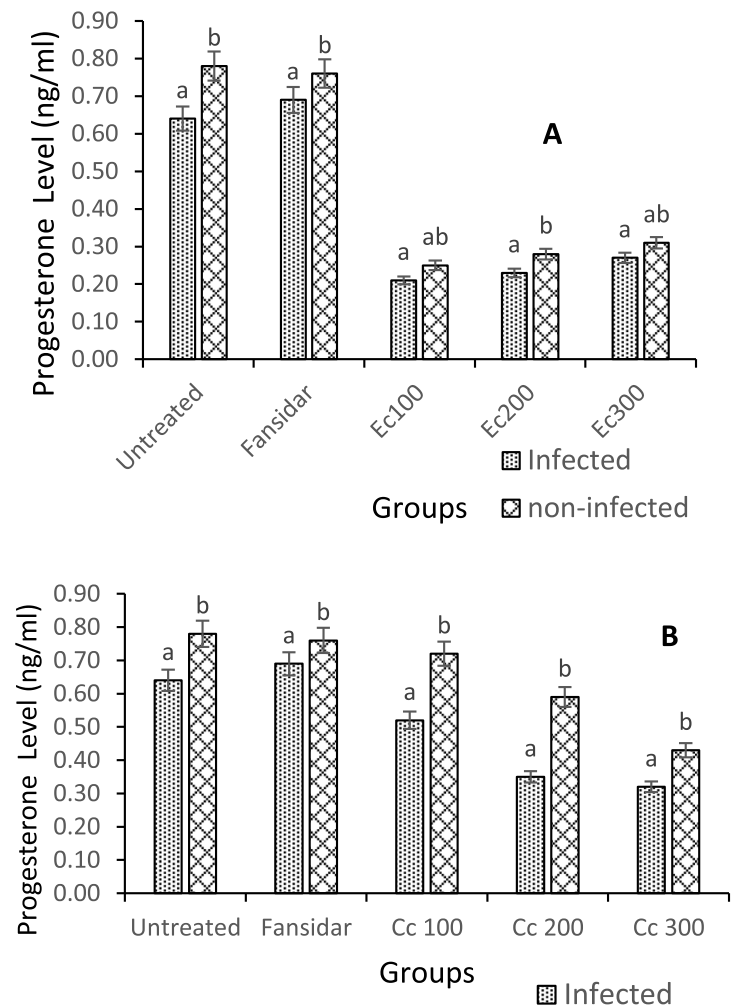

囚non-infected

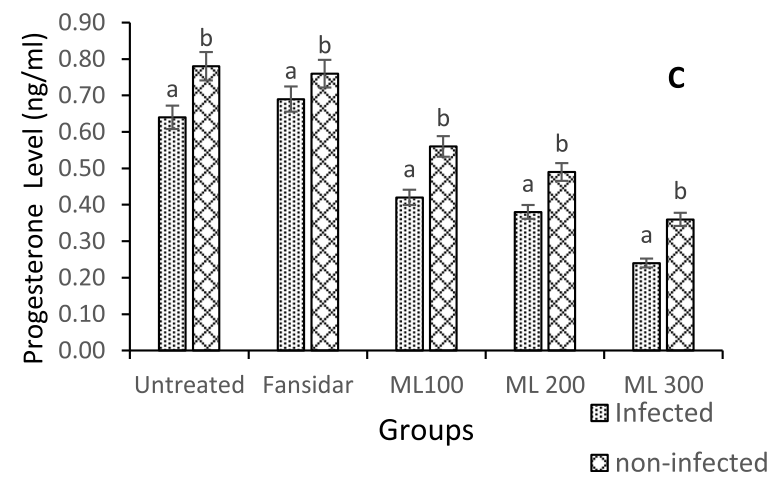

Fig. 1 Effect of different plant extracts on Progesterone level of mice treated with a E. chlorantha (Ec), b C. citratus (Cc), and $M$. lucida (ML) extracts

the observed antimalarial activity in the group treated with M. lucida may be attributed to its high alkaloid and flavonoid contents. Previous works also showed the antimalarial activity of alkaloids and flavonoids in plants (Balogun et al. 2009; Okokon et al. 2005).

Bark extract of $E$. chlorantha in this study showed a significant chemosuppression up to $74.32 \%$ in pregnant mice in a 6-day treatment. Other studies have reported similar findings in in-vivo evaluation of $E$. chlorantha against $P$. berghei-infected mice (Agbaje and Onabanjo 1991; Ogbonna et al. 2008).
The leaf extract of $C$. citratus recorded the least chemosuppression in this study with chemosuppression of up to $55.56 \%$ in pregnant mice in a 6 -day treatment. This implies that $C$. citratus leaf extract possess minimal antiplasmodial activity hence might not be a good candidate for an alternative source of anti-malaria. This result confirmed earlier findings on in-vivo and in-vitro activities of C. citratus extract against Plasmodium parasites (Idowu et al. 2010; Kimbi and Fagbenro-Beyioku 1996).

All the extracts showed chemosuppression property which was significantly different when compared to the infected non-treated group. A complete clearance was observed in the positive control group treated with Fansidar, in the 6-day treatment. While the plant extracts showed ability to suppress parasitaemia, none was able to achieve complete parasite clearance in the 6-day treatment with extracts. This might be due to the fact that the plant extracts are in their crude forms with the active ingredients not having been isolated and compressed into active drugs (Adzu and Haruna 2007; Ebiloma et al. 2011; Idowu et al. 2014).

The fact that extract of E. chlorantha induced abortion (determined jointly by drastic loss of weight, fetal absorption, and presence of prominent endometrial glands in the oviduct) is an indication that this plant possessed abortifacient properties. This findings supports the claim by the herb sellers (that E. chlorantha can cause abortion), though some of them still prescribe it to pregnant women believing that taking a "small quantity" should pose no harm to the developing fetus. Unfortunately, there is no standard measurement for dosage requirements.

Similarly, extracts of C. citratus and M. lucida caused miscarriage in both infected and non-infected pregnant mice. A recent study also mentioned Morinda citrifolia (Linn.) belonging to the same family (Rubiaceae) with M. lucida as one of the herbs with abortifacient property (Singh et al. 2018).

However, occurrence of miscarriage was higher in the infected groups compared to the non-infected groups. Relationship between malaria and miscarriage is poorly understood. Studies on the relationship between malaria and miscarriage showed contradictory results (SchantzDunn et al. 2009; Takem and D'Alessandro 2013). However, this study showed that there could be a negative interaction between the use of herbs and malaria parasite infection during pregnancy. A study revealed that malaria parasite infection can reduce progesterone level in female mice (Adejuwon and Adejuwon 2005). Couple with this, are the constituents of the plant extracts. The major constituents common to these plants and responsible for their antiplasmodial activities are alkaloids, flavonoids, and saponins (Olanlokun and Akomolafe 2013)

These are known compounds to exhibit antifertility properties (Hiremath and Hanumantharo 1990; Wang 
and Ruan 1996). Alkaloid-like constituents were reported to be responsible for the suppressant effect on the uterine normal contraction and high anti-implantation activity exhibited by extract of Graptophyllum pictum (Stella et al. 2009).

The fact that progesterone level was low in mice treated with the plant extracts is an implication that these plant extracts possessed anti-progestogenic potential and this could further explain the cause of miscarriage observed in the pregnant mice. Studies have shown that some herbs could be anti-progestogenic (Ahmed et al. 2014; Al-Snafi 2015). The decline in progesterone in this study intensified with increase in dosage, hence explaining the increase in number of miscarriage as dosage progresses.

Progesterone act on the central nervous system, ovary and uterus, and are important for ovulation, fertilization, implantation of embryo, maintenance of pregnancy, mammary gland development, and lactation (Lydon et al. 1995; Graham and Clarke 1997).

Furthermore, progesterone is also important in suppressing the maternal immunologic response to fetal antigens, thereby preventing maternal rejection of the trophoblast (Kumar and Magon 2012).

Studies have shown that alkaloids containing plants could impair progestogenic activities (Ramya et al. 2011; Singh et al. 2018), thereby facilitating abortion and/or miscarriage. The results also suggested that these plants possessed embryotoxic (death of fetus in the uterus) properties (De Freitas et al. 2005).

It is however worrisome that there is dearth of information on the effect of these commonly used herbs against malaria on pregnancy in Nigeria. Few studies on plants with abortifacient properties did not mention these plants (Ramya et al. 2011; Ahmed et al. 2014; Takem and D'Alessandro 2013). In fact, a recent study on traditional and medicinal uses of Morinda lucida from Nigeria claimed that M. lucida posed no risk to pregnant women without any study or experiment to proof this (Adeleye et al. 2018).

More so, studies have shown that pregnant women and mothers with infants, the population that frequently uses these substances, also believe that they have no adverse reactions or toxic effects. Thus, they rarely seek information from health care professionals about herbal products (Clarke et al. 2007). However, the use of any substance, either natural or synthetic by pregnant women, must always take into account the risk-benefit ratio (Sanseverino et al. 2001).

\section{Conclusion}

About 17 different plants were known to be useful in management of malaria during pregnancy in this study. Of the three plants evaluated, extract of M. lucida produced the highest chemosuppression in Plasmodium berghei-infected pregnant mice. Extract of E. chlorantha also demonstrated good antiplasmodial properties in Plasmodium berghei-infected pregnant mice. All the plant extracts possessed abortifacient/embryotoxic properties through a mechanism that reduces the progestogenic activities of the ovary. In order to reduce the risk of danger posed by use of herbs in pregnancy on mothers and the developing fetus, there is need for proper awareness on the possible abortifacient and teratogenic properties of herbs used in management of malaria during pregnancy by Government and other concerned agencies.

\section{Abbreviations \\ TBH: Traditional birth home; PAM: Pregnancy-associated malaria; GD: Gestational day; TP: Traditional practitioners; TBA: Traditional birth attendance; MP: Malaria parasitaemia; Cc: Cympobogon citratus; Ec: Enanthia chlorantha; MI: Morinda lucida; SP: Sulphadoxine pyremethamine; M. lucida: Morinda lucida; C. citratus: Cympobogon citratus; E. \\ Chlorantha: Enanthia chlorantha}

\section{Acknowledgements}

Our appreciation goes to the undergraduate students of the department of pure and applied zoology that helped during the research. We also want to appreciate the Institute of Medical Research and Advance Training, UCH Ibadan for providing us with the parasite. Finally, we want to appreciate the traditional practitioners, pregnant women, Older men and women, who volunteered to participate in this study.

\section{Authors' contributions}

BAS conceptualized this research. BAS and IOA designed the research protocol and methodology. BAS and IOA carried out the field work. AKO provided literatures and other technical inputs. OJ and RSA prepared reagents for biochemical analysis and also prepared and read the histological slides. BSA did the statistical analysis and developed the manuscript. All the authors read, correct, and approved the final manuscript.

\section{Funding}

This research did not receive any specific grant from funding agencies in the public, commercial, or not-for-profit sectors.

\section{Availability of data and materials}

The datasets generated during and/or analyzed during the current study are not publicly available due [General agreement among the authors] but are available from the corresponding author on reasonable request.

\section{Ethics approval and consent to participate}

Nigeria Institute of Medical Research gave approval to use the animals for this study. Approval for the research was also granted by the Department of Pure and Applied Zoology review committee on $27^{\text {th }}$ July, 2018, after making a presentation on the research proposal with reference No. PG120388/002/018. Experiments were performed in accordance with the Guide of the Care and Use of Laboratory Animals of the National Institutes of Health.

\section{Consent for publication}

The authors gave their consent to the Bulletin of Natural Research Centre to publish this manuscript if accepted for publication.

\section{Competing interests}

The authors declare that they have no competing interests.

\section{Author details}

${ }^{1}$ Malaria Research Unit, Department of Pure and Applied Zoology, Federal University of Agriculture, Abeokuta, Nigeria. ${ }^{2}$ Physiology Research Unit, Department of Pure and Applied Zoology, Federal University of Agriculture, Abeokuta, Nigeria. ${ }^{3}$ Pharmacology Research Unit, Department of Veterinary 
Physiology and Pharmacology, Federal University of Agriculture, Abeokuta, Nigeria.

\section{Received: 14 July 2020 Accepted: 14 August 2020}

Published online: 09 September 2020

\section{References}

Abolaji AO, Eteng MU, Ebong PE, Brisibe EA, Nurul Kabir AD, Choudhary MI (2012) A safety assessment of the antimalarial herb Artemisia annua during pregnancy in Wistar rats. Phytother Res 12:1-8

Adamson SL, Lu Y, Whiteley KJ, Holmyard D, Hemberger M, Pfarrer C, Cross JC (2002) Interactions between trophoblast cells and the maternal and fetal circulation in the mouse placenta. Dev Biol 250(2):358-373

Adebiyi OE, Abatan MO (2013) Protective effects of Enantia chlorantha stem bark extracts on acetaminophen induced liver damage in rats. Jordan J Biol Sci 6(4):284-290

Adejuwon CA, Adejuwon AO (2005) Serum steroid in mice infected with Plasmodium berghei berghei. J Med Sci 5(3):212-215

Adeleye OO, Ayeni OJ, Ajamu MA (2018) Traditional and medicinal uses of Morinda lucida. Journal of Med Plants Studies 6(2):249-254

Adeniran A, Goodman OO, Olatona FA, Oluwole EO (2016) Malaria prevention in pregnancy among traditional birth attendants in rural Lagos, Nigeria. Journal Commun Med Prim Health Care 28(1):8-16

Adzu B, Haruna A (2007) Studies on the use of Zizyphus Spina-Christi against pain in rats and mice. Afr J Biotechnol 6:1317-1324

Afolabi OJ, Abejide AE (2020) Antiplasmodial activities of Morinda lucida (Benth) and Alstonia boonei (De wild) in mice infected with plasmodium berghei. Bull National Res Centre 44:85. https://doi.org/https://doi.org/10.1186/s42269020-00342-8

Agbaje EO, Onabanjo AO (1991) The effects of extracts of Enantia chlorantha in malaria. Ann Trop Med Parasitol 85:585-590

Ahmed HMM, Yeh J, Tang Y, Cheng WT, Ou B (2014) Molecular screening of Chinese medicinal plants for progestogenic and anti-progestogenic activity. J Biosci 39:453-461

Al-Snafi AE (2015) Encyclopedia of the constituents and pharmacological effects of Iraqi medicinal plants. Rigi Publication India 1:12-15

Astin JA (1998) Why patients use alternative medicine? Results of a national study. J Am Med Assoc 279:1548-1553

Avwioro G (2010) Effectiveness of some medicinal plant decoction in the treatment of malaria in Nigeria. Annals of Biological Research 1(2):230-237

Babalola AS, Idowu OA, Sam-Wobo SO, Fabusoro E (2015) Risk factors associated with the occurrence of placenta malaria among a population of parturients in Abeokuta. Malaria World J 6:8

Babalola AS, Idowu OA, Sam-Wobo SO, Fabusoro E (2017) Antenatal care attendance, intermittent preventive treatment and occurrence of malaria parasite infection at parturition in Abeokuta, Nigeria. Int J Trop Dis Health 21(4):1-10

Balogun EA, Adebayo JO, Zailani AH, Kolawole OM, Ademowo OG (2009) Activity of ethanolic extract of Clerodendrum violaceum leaves against Plasmodium berghei in mice. Agric Biol J N Am 1:307-312

Banda Y, Chapman V, Goldenberg RL, Stringer J, Culhane JF, Sinkala M (2007) Use of traditional medicine among pregnant women in Lusaka Zambia. J Altern Complement Med 13(1):123-127

Bello FA, Morhason-Bello IO, Olayemi O, Adekunle AO (2011) Patterns and predictors of self-medication amongst antenatal clients in Ibadan, Nigeria. Nigerian Med J 52(3):153-158

Clarke JHR, Rates SMK, Bridi RA (2007) Warning about the use of plant products in pregnancy. Infarma 19(1-2):41-48

Dalal SJ, Estep JS, Valentin-Bon IE, Jerse AE (2001) Standardization of the Whitten effect to induce susceptibility to Neisseria gonorrhoeae in female mice. Contemp Top Lab Anim Sci 40(2):13-17

De Freitas TG, Augusto PM, Montanari T (2005) Effect of Ruta graveolens L. on pregnant mice. Contraception 71:74-77

Dike IP, Obembe OO, Adebiyi FE (2012) Ethnobotanical survey for potential antimalarial plants in South-Western Nigeria. J Ethnopharmacol 144(3):618-626

Ebiloma GU, Omale J, Aminu RO (2011) Suppressive,curative and prophylactic potentials of Morinda lucida (Benth) against erythrocytic stage of mice infective Plasmodium berghei NK-65. Br J Appl Sci Technol 1(3):131-140

Fakaye, T.O., Adisa, R. and Musa, I.E. 2009. Attitude and use of herbal medicines among pregnant women in Nigeria. BMC Complementary Alternative Med 2009; doi:https://doi.org/10.1186/1472-6882-9-53. [PMC free article] [PubMed]
Graham JD, Clarke CL (1997) Physiological action of progesterone in target tissues. Endocr Rev 18:502-519

Hiremath SP, Hanumantharo S (1990) Antifertility efficacy of the plant Striga lutea (scropholariacae) on rats. Contraception 42(4):467-477

Idowu OA, Ajana OO, Soniran ST, Aworinde DO (2010) Ethnobotanical survey of antimalarial plants used in Ogun state Southwest-Nigeria. Afr J Pharm Pharmacol 4(2):55-60

Idowu OA, Babalola AS, Adenubi OT, Olukunle JO (2014) Antiplasmodial activities of combined extracts of Morinda morindiodes, Morinda lucida and Vernonia amygdalina in Plasmodium berghei infected mice. Zoologist 11:40-45

Idowu OA, Mafiana CF, Dapo S (2008) Traditional birth home attendance and its implications for malaria control during pregnancy in Nigeria. Trans R Soc Trop Med Hyg 102(7):679-684

Kamatenesi-Mugisha M, Oryem-Origa H (2007) Medicinal plants used to induce labour during childbirth in western Uganda. J Ethnopharmacol 109:1-9

Kazembe T, Munyarari E, Charumbira I (2012) Use of traditional herbal medicines to cure malaria. Bull Environ Pharmacol Life Sci 1(4):63-85

Kimbi HK, Fagbenro-Beyioku AF (1996) Efficacy of Cymbopogon giganteus and Enantia chrantha against chloroquine resistant Plasmodium yoelii nigeriensis. East Afr Med J 73(10):636-637

Kumar P, Magon N (2012) Hormones in pregnancy. Nigerian Med J 53(4):179-183

Lydon JP, DeMayo FJ, Funk CR, Mani SK, Hughes AR, Montgomery CA, Shyamala G, Conneely OM, O'Malley BW (1995) Mice lacking progesterone receptor exhibit pleiotropic reproductive abnormalities. Genes Dev 9:2266-2278

Malan DF, Neuba DFR (2011) Traditional practices and medicinal plants use during pregnancy by Anyi-Ndenye women (eastern Côte d'lvoire). Afr J Reprod Health 15(1):85-93

Maroyi A (2013) Traditional use of medicinal plants in south-Central Zimbabwe: review and perspectives. J Ethnobiol Ethnomed 9:31

Mbura JS, Mgaya HN, Heggenhougen HK (1985) The use of oral herbal medicine by women attending antenatal clinics in urban and rural Tanga District in Tanzania. East Afr Med J 62:540-550

Nergard CS, Than Ho TP, Diallo D, Ballo N, Paulsen BS, Nordeng H (2015) Attitudes and use of medicinal plants during pregnancy among women at health care centres in three regions of Mali, West-Africa. J Ethnobiol Ethnomed 11:73

Ogbonna DN, Sokari TG, Agomoh AA (2008) Antimalarial activities of some selected traditional herbs from south eastern Nigeria against Plasmodium species. Res J Parasitol 3(1):25-31

Okokon JE, Ofodum KC, Ajibesin KK, Danladi B, Gamaniel KS (2005) Pharmacological screening and evaluation of antiplasmodial activity of Croton zambesicus against Plasmodium berghei berghei infection in mice. Indian J Pharmacol 37:243-246

Olanlokun JO, Akomolafe SF (2013) Antioxidant potentials of various solvent extracts from stem bark of Enantia chlorantha. J Biomed Sci Eng 6:877-884

Oshonwo FE, Nwakwo GC, Ekiyor CP (2014) Traditional birth attendants and women's health practices: a case study of Patani in southern Nigeria. J Public Health Epidemiol 6(8):252-261

Pakrashi A, Bhattacharya N (1977) Abortifacient principle of Achyranthes aspera Linn. Indian J Exp Biol 15(10):856-858

Ramya R, Sivasakthi R, kumar, C.S. (2011) Preliminary phytochemical and antifertility studies on Dodonea viscosa Linn. Asian J Res Pharm Sci 1(3):77-79

Rogerson SJ, Hviid L, Duffy PE, Leke RFG, Taylor DW (2007) Malaria in pregnancy: pathogenesis and immunity. Lancet Infect Dis 7:105-117

Rossant J, Cross JC (2001) Placental development: lessons from mouse mutants. Nat Rev Genet 2:538-548

Sanseverino MTV, Spritzer DT, Schulerfaccini L (2001) Teratogenesis manual. Porto Alegre, UFRGS publishers:423-450

Schantz-Dunn J, Nawal MDM, Nour MD (2009) Malaria and pregnancy: a global health perspective. Rev Obstet Gynecol 2(3):186-193

Seely D, Dugoua JJ, Perri D, Mills E, Koren G (2008) Safety and efficacy of panax ginseng during pregnancy and lactation. Can J Clin Pharmacol 15(1):87-94

Singh R, Kakar S, Shah M, Jain R (2018) Some medicinal plants with anti-fertility potential: a current status. J Basic Clin Reprod Sci. https://doi.org/10.4103/ 2278-960X.194512

Stella OO, Grace EU, Herbert A, Coker A, Samuel AA (2009) Oxytocic and antiimplantation activities of the leaf extracts of Graptophyllum pictum (Linn.) Griff. (Acanthaceae). Afr J Biotechnol 8(21):5979-5984

Takem NE, D'Alessandro U (2013) Malaria in pregnancy. Mediterranean J Infect Dis Haematol 5:e2013010 
Towns AM (2014) Fertility and fontanels: Women's knowledge of medicinal plants for reproductive health and childcare in western Africa. Leiden University, Doctoral thesis, p 2014

Ukibe SN, Ikeako LC, Mbanugo Jl, Obi-Okaro AC (2014) Knowledge attitude and practices of pregnant women concerning use of insecticide treated bed nets (ITNs) in Anambra state, south East Nigeria. J Appl Med Sci 3:15-22

Ukpai OM, Amaechi EC (2012) Evaluation of in-vivo antimalarial activity of the ethanolic leaf extracts of Chromolaena odorata and Cymbopogon citratus in mice. Nigeria J Biotechnol 24:27-34

Unyime IE, Idongesi LJ, Akpabio EA (2016) High patronage of traditional birth homes: a report from Akwa Ibom, southern Nigeria. Am J Health Pol Manag $1(1): 1-6$

Varga CA, Veale DJ, Isihlambezo H (1997) Utilization patterns and potential health effects of pregnancy-related traditional herbal medicine. Soc Sci Med 7:911-924

Wang JY, Ruan Al (1996) Triterpenes of Marsdenia globifera for antifertility. Chin Pharm J 31:266-269

Yusuff KB, Omarusehe LD (2011) Determinants of selfmedication practices among pregnant women in Ibadan, Negeria. Int J Clin Pharm 33:868-875

\section{Publisher's Note}

Springer Nature remains neutral with regard to jurisdictional claims in published maps and institutional affiliations.

\section{Submit your manuscript to a SpringerOpen ${ }^{\circ}$ journal and benefit from:}

- Convenient online submission

- Rigorous peer review

- Open access: articles freely available online

- High visibility within the field

- Retaining the copyright to your article

Submit your next manuscript at $\boldsymbol{\nabla}$ springeropen.com 